\title{
Museologi I Finland
}

\author{
Janne Vilkuna
}

\section{OM DE FÖRSTA MUSEERNA}

Finlands första museisamlingar grundades i Åbo under 1700-talet, men Åbo brand förstörde dem 1827. Följande år började man bygga upp naturhistoriska samlingar vid Helsingfors universitet och 1829 grundades de historiska samlingarna. År 1846 bildades Finlands konstförening i Helsingfors med konstutställningar på programmet. Tre år senare, 1849, tillkom Helsingfors universitets mynt-, medalj- och konstkabinett med funktion även som etnografiskt museum. Snart, 1857, började museet hållas öppet för publik och det fick 1868 namnet Historiskt-etnografiskt museum. Ar 1870 grundades Finlands fornminnesförening, 1876 Studentkårens etnografiska museum.

Ár 1883 antogs en fornminneslag (den förnyades 1963), som lade ansvaret för landets fornminnen på en enligt lagen inrättad arkeologisk kommission (efter 1970 med benämningen Museiverket). Dess första och även Finlands första - museitjänsteman var statsarkeologen. Kommissionen fick 1892 fem tjänster för de arkeologiska, etnografiska och historiska samlingarna. Nästa år sammanfördes de olika kulturhistoriska samlingarna till Statens historiska museum, som 1917 gavs namnet Nationalmuseum och blev kulturhistoriskt centralmuseum. Det utgör numera en avdelning av Museiverket.

Det första finska lokalmuseet grundades 1862 i Brahestad och 1881 tillkom Ábo stadsmuseum. Museientusiasmen var stor och vid sekelskiftet 1900 fanns det redan 12 stadsmuseer i våra 37 städer. De statliga museerna hade personal med vetenskaplig utbildning, men lokalmuseerna sköttes av entusiaster som hade svårigheter med både vetenskapliga och museala frågor.

Vid sekelskiftet, då museerna hade stabiliserat sin position, började man även tala om tre museala begrepp: museografi, museivetenskap och museiteknik. År 1909 framlade museikommittén ett betänkande. Där föreslogs bland annat att museernas vård skulle förbättras genom publiceringen av en handbok om museernas vårdfrågor och genom museikurser.

Men tiden gick, första världskriget kom och finska inbördeskriget. Först 1923 anordnades de första museidagarna i Helsingfors. Då grundades Finlands Museiförbund, Suomen Museoliitto, som bland annat intresserade sig för utbildningsfrågan. Förbundets förste ordförande var arkeologen Julius Ailio, sedermera utbildningsminister. Andra museidagarna hölls 1926 och två år senare, 1928, organiserade förbundet den första museikursen vid Nationalmuseet. Detta var alltså den första allmänna "yrkesutbildande" museikursen i Finland.

Dock gick utvecklingen långsamt. På museidagarna i Helsingfors 1935 klagade man över bristerna $\mathrm{i}$ museiarbetets vetenskapliga grund. I många fall var förvärven vid denna tid helt och hållet föremålscen- 
trerade och katalogernas - om sådana gjordes - uppgifter berörde sällan annat än föremålet själv, dess givare och förvärvsorten. Föremålens kontext och de fenomen de representerade har börjat intressera oss först under de senaste decennierna - och det finns ännu mycket att göra härvidlag.

År 1939 började krigsåren. Efter freden 1944 uppmuntrades hembygdsrörelsen och inom denna väldiga rörelse grundades hundratals hembygdsmuseer under 1940-, 50och 60-talen. De utgör grunden för den positiva - om än tyvärr konservativa - hållning till museerna som dagens publik visar. Museiförbundet arrangerade 1948 en kurs för studerande - alltså inte färdiga museiarbetare! - i praktiska museifrågor. Under 1950- och 60-talen började stads- och landskapsmuseerna inrätta de första fasta tjänsterna.

\section{MUSEIVÄSENDET VÄXER}

Vid skiftet mellan 1960- och 70-tal fanns utanför de statliga museerna endast omkring ett dussin museer med heltidsanställd personal. Den kommitté som hade till uppgift att utreda museernas regionala organisation och en museilag, kom 1973 med sitt betänkande och 1979 statsrådets beslut om museernas statsbidrag. Samtidigt etablerades de regionala näten av kulturhistoriska museer och konstmuseer, en motsvarighet till den svenska länsmuseistrukturen. Beslutet satte fart på utvecklingen. Museernas ställning befrämjades ytterligare med nya statsbidragslagar: museilagen 1989 och dess ersättare 1993. Den senare ger statsbidrag inte endast till de regionala museerna utan till varje museum med fasta tjänster.

Finlands hembygdsförbund hade under 1960-talet utgivit några handböcker som också behandlade hembygdsmuseer och deras vård. Men i praktiken fick man först 1985 en allmänt använd bok på området alltså en sådan bok som redan museikommittén 1909 längtat efter. Då publicerades Museiverkets Museonhoidon opas paikallismuseoille (Handbok för lokalmuseernas vård).

Trots statsbidragslagen saknar Finland ännu en lag eller motsvarande dokument som klart definierar museernas uppgifter i samhället. Detta är ett akut problem då statsbidragen ges till museernas huvudmän. De flesta museerna är kommunalt ägda även de regionala museerna - och när kommunerna nu befinner sig i djupa ekonomiska svårigheter, skär man i sin budget och vidmakthåller endast den service som är "livsviktig" grundservice. Den service som är bestämd och preciserad i lag ses automatiskt som grundservice - allt annat är extra och kan minskas eller strykas.

I Finland finns idag över 800 museer och över 100 av dem har tillsammans ca 1.500 permanenta tjänster - till ca hälften av dem krävs akademisk examen. Dessutom finns säkerligen minst lika många tillfälliga arbetare.

\section{MUSEIKURSER VID UNIVERSITETEN}

Fram till 1980-talet erhölls den museala yrkeskompetensen inom de akademiskt rekryterade tjänsterna först genom praktik på arbetsplatsen - forskarutbildning hade man fått vid universitetet.

År 1964 arrangerades med hjälp från Museiförbundet den första museitekniska kursen vid Helsingfors universitet. Den riktade sig till etnologistuderande och tillhörde cum laude-nivån. Under 1960- och 70- 
talen organiserade universitetets olika institutioner årligen museikurser, senare anordnade arkeologiska, etnologiska och konsthistoriska institutionerna $\mathrm{i}$ samarbete årligen en kurs.

På 1970-talet organiserade också andra högskolor museikurser.

\section{MUSEOLOGIN BLIR AKTUELL}

Under 1970-talet diskuterades mycket inom museiväsendet om utbildningsfrågan och 1975 gjordes vid Helsingfors universitet en utredning om saken. År 1980 förändrades Finlands Museiförbunds tjänst som utställningssekreterare till tjänst som utbildningssekreterare: förbundet har sedan dess årligen organiserat 5-10 fortbildningskurser.

Finska Museiförbundets centralstyrelse tillsatte 1980 en arbetsgrupp, vars uppgift var att upprätta en plan för universitetens museologiska undervisning. Gruppens förslag publicerades 1982. Museiförbundets generalsekreterare Jorma Heinonen skrev 1983: Museologi är den enda vetenskap, utom biblioteksvetenskap och informatik som är fast bunden till en sambällsinstitutions verksambet. Om vi anser denna koppling till museet och dess konkreta, aktuella, uppgifter som den enda grunden for museologin och dess studium, blir resultatet haltande och skadligt for museiverksambetens framtida utveckling. Om $v i$ idag strävar efter att med museologisk utbildning endast tillgodose de dagliga behoven $i$ museiarbetets praktik, rảkar vi på lång sikt in i en återvändsgränd. Museiverksambeten behöver for att utvecklas en grundlig teoretisk analys av sin innebörd, sina uppgifter och sin metodutveckling. Därför borde vi inrätta en museologisk lärostol i landet under vilken även fortbildning och vetenskaplig forskning skulle vara möjliga.
Ar 1988 publicerade Museiförbundet boken Museologian perusteet (Museologins grunder) av museicheferna Jouko Heinonen och Markku Lahti.

\section{MUSEOLOGISK UNDERVISNING INLEDS VID UNIVERSITETEN}

I studier som förbereder för museiverksamhet har man brukat tala om "museiämnen". I Finland har dessa vid museer för konst och kulturhistoria varit arkeologi, etnologi, historia och konsthistoria. Vid universiteten bygger fil kand-examen på utbildningsprogram med bestämda läroämnen som studeras på tre nivåer eller studie-enheter: approbatur, cum laude och laudatur; en examen kan exempelvis bestå av ett laudatur, två cum laude och ett approbatur. Detta system kommer troligen vid mitten av 90-talet att ersättas av ett system som medger de studerande att mera fritt välja sina studiers ämnes- och examensstruktur.

Vid Åbo universitet började man 1982 den egentliga museologiska undervisningen, alltså med museologi som självständigt läroämne. Den syftade till ett approbatur. Vid Jyväskylä universitet inleddes museikurser 1974 och under sommarterminerna 1981 och 1983 ordnades en veckas intensivkurser i museologi. Dessa var först och främst avsedda för personer som redan arbetade i museer. Höstterminen 1983 inrättades ett program, en "examenshelhet", som inleddes med approbatur-undervisning i museologi. Examenshelheten omfattar ett laudatur i ett museiämne, $t$ ex etnologi, ett cum laude som första biämne i t ex konsthistoria, ett approbatur i ett andra biämne, samt ett approbatur i museologi som tredje biämne.

Läroämnets struktur vilade både i Åbo 
70 och Jyväskylä på förslaget från Museiförbundets arbetsgrupp, dock så att den i Jyväskylä även innehöll praktik vid ett professionellt museum.

\section{MUSEOLOGISK UNDERVISNING IDAG}

Idag erbjuds universitetsutbildning i museologi vid Åbo och Jyväskylä universitet, Åbo akademi samt Uleåborgs och Helsingfors universitet. År 1989-90 diskuterade representanter för dessa universitet sinsemellan och med Musei-förbundets, Museiverkets och Undervisnings-ministeriets representanter om museologins ställning. Man överenskom att en gemensam nivå de olika kurserna om ca 20 studieveckor skulle eftersträvas, även om innehållet kunde ha olika betoning.

I Jyväskylä, Åbo och Helsingfors universitet är museologi självständigt läroämne. I Jyväskylä och Helsingfors omfattar studierna på 20 studieveckor (motsvarar lika många poäng enligt det svenska studiesystemet) vari ingår en praktikperiod på 6 veckor vid ett museum (räknas i Jyväskylä som 2 studieveckor, i Helsingfors får 3 månaders praktik motsvara 4 studieveckor). I Åbo universitet omfattar studierna 15 studieveckor utan praktik. Vid Åbo Akademi ingår de museologiska studierna (6 studieveckor) obligatoriskt i de konsthistoriska och etnologiska studierna. År 1994 skall Åbo universitet och Akademi samarbeta i sin museologiska undervisning för ett approbatur (20 studieveckor) med praktik.

Vid Uleåborgs universitet ingår ämnet med 2 studieveckor i historiestudiet. Dessutom har man en praktikperiod på 3 studieveckor (8 arbetsveckor) vid ett museum på ett landskapsmuseums nivå.

Vid Helsingfors universitet har studeran- de $\mathrm{i}$ arkeologi, etnologi, konsthistoria eller historia i sina studier kunnat infoga en (5 studieveckors) museiteknisk kurs. Från läsåret 1992-93 har undervisning givits på approbaturnivå till 15 utvalda studerande som avslutat cum laude-studier i sitt huvudämne.

I Helsingfors examineras ämnet separat, men i Jyväskylä kan man antingen låta det ingå $\mathrm{i}$ en examenshelhet eller examineras separat. I Åbo kan ämnet ingå i examen från höstterminen 1993. Om man läser den museala examenshelheten i Jyväskylä väljer man att studera ett $s \mathrm{k}$ museiämne - etnologi, historia eller konsthistoria (arkeologi kan inte läsas som huvudämne i Jyväskylä) - som huvudämne och sedan har man ett annat museiämne som första sidoämne. Som andra eller tredje sidoämne har man museologi.

Sedan 1989 har Jyväskylä haft en tjänst i museologi, "överassistent”, i museologi. Tjänsten är tills vidare den enda i Finland. Den är ansluten till den konsthistoriska institutionen, så att museologi tillsammans med konsthistoria är institutionens läroämnen. I Åbo är studierna underordnade den arkeologiska lärostolen och i Helsingfors är studierna samordnade av arkeologiska, etnologiska, historiska och konsthistoriska institutionerna - läsåret 1992-93 hade den arkeologiska institutionen ansvaret.

Jyväskylä universitet har ett universitetsmuseum med kultur- och naturhistorisk avdelning (i framtiden också konstavdelning). Överassistenten i museologi är från 1993 chef för museet. Museologin och museets arbete samordnas så att museet skall fungera som ett museologiskt "undervisningslaboratorium".

Eftersom museologi faktiskt är det enda verkliga museiämnet och det arbetande 
museets kompetensbehov - oavsett samlingarnas innehåll - främst gäller förvärvs- och dokumentationsansvar, öppnades approbaturkursen i Jyväskylä läsåret 1992-93 för alla studerande vid universitetet, oavsett deras huvudämne. Läsåret 1993-94 börjar undervisningen på cum laude-nivå. Fastän lokal- och företagshistorieskrivning blomstrar i Finland har ännu inte museiväsendets historia skrivits. Därför har museologiämnet tagit detta ämne som projekt, vilket bl a innebär att cum laude-uppsatsernas ämnen är historiskt inriktade.

Då laudatur-nivån tills vidare inte finns, kan de studerande göra sina laudatur (eller vid några universitet också sina cum laude) avhandlingar, liksom även licentiat- och doktorsavhandlingar t ex i etnologi, historia och konstvetenskap så att arbetet också innehåller en museologisk aspekt.

Det finns också efterfrågan på separata museologiska kurser. Jag menar först och främst från museernas tekniska personal, som vanligen inte alls eller mycket litet erhåller allmän museal undervisning före eller under sitt arbete vid museet. Museiförbundet har varit den enda organisation som anordnat korta museikurser. Också specialmuseernas personal, som kan vara allt mellan flygpiloter och pappersingenjörer kunde ha nytta av en allmän museologisk orientering. Problemet kan lösas - och har redan delvis lösts - genom att de universitet som erbjuder museologisk undervisning kan efter ansökan medge en person rätt att studera museologi som en fristående kurs.

Ett problem är, att då man numera försöker minska studietiden och då museologi bara kan ingå i examen som sidoämne (så i Jyväskylä), kan en studerande - om han eller hon väljer de kombinationer där stake- tet är lägst - få examen med endast två forskarämnen. Är detta för snävt? Om man tänker sig i framtiden ge även högre museologisk utbildning, då måste museologi kunna vara ett huvudämne i grundexamen.

\section{MUSEOLOGINS FRAMTID}

En fördel med museologiundervisningen är att man med dess hjälp hela tiden kan få nya och moderna impulser via nya medarbetare och inte endast stelnar i de arbetsformer som tillämpats åratals. Införandet av datorisering - eller rättare sagt det motstånd som den mötte på 1980-talet - är ett bra exempel på det gamla systemets förmåga att ta emot nya, otvivelaktigt nyttiga, innovationer.

När det nu finns ca 1.500 tjänster i Finlands museer och innehavarnas genomsnittsålder är ca 30-40 år eftersom verksamheten särskilt expanderade under 70 - och 80-talen, har man ställt sig frågan att om verksamhetens omfattning minskar under de närmaste åren - är det då inte lättsinnigt att utbilda så många studerande som de ca 50-60 som årligen börjar. Det finns nog ingen fara för överutbildning. De som är bekymrade måste komma ihåg att läroämnet är ett sidoämne och att huvuddelen av de nu museiverksamma pensioneras på 2000-2010-talen - alltså bara om 10-20 år. Det är naturligtvis också bra om musealt utbildade personer kan finna anställningar utanför museiväsendet, till exempel inom press eller kulturadministration.

Museologins framtid beror dock framför allt på hur museerna utvecklas och hur samhället ser på deras funktion. Det är klart att när museernas basarbete haltar, är museologin och dess utveckling inte någon genväg genom problemen, men museolo- 
72 gisk kunskap är otvivelaktigt en tillgång. Det är också utomordentligt betydelsefullt att man både inom museer och universitet förstår ämnets betydelse. Faktum är, att museologin och dess studium nu är internationellt etablerade, att om vi vill befrämja våra natur- och kulturminnens bevarande, liksom forskning och information om dem, måste vi vara medvetna om den nordiska och internationella museologiska utvecklingen och helst inte bara vara medvetna utan också att själva utveckla den.

\section{SUMMARY}

\section{Museology in Finland}

The development of museums was severely impended first by the Civil War of 1918 and then by the Second World War. However in 1923 the Finnish Museums Association had been formed, and museum training had a prominent place on its agenda. A training course was arranged in 1928 . However in the 30's the complaint was made that the profession lacked a scientific basis. New efforts were made after the war, in 1948. In the 1950's and 60's the first permanent posts were established in local and regional museums. In the 70's new legislation granted economic support to both museums of art and of cultural history in the regions, which led to a considerable growth in the number of employees. Today Finland has more than 800 museums and more than 100 of them have a total of 1.500 permanent posts.

Until the 1980's professional competence was gained through in-service training, although technical courses had been arranged since 1964 for students of archaeology, anthropology and history of art at the university of Helsinki. Museology courses proper were instituted in 1982 at the University of Åbo and in the following year at Jyväskylä. At Jyväskylä the only post in Finland as reader in museology has been attached to the Department of Art History. At the University of Helsinki a museology course was established in 1992/
93 with very restricted admission. Museology is also offered at Åbo Academy and the university of Oulu. All those organising the courses have agreed that the basic museology course should have a minimum duration of 20 weeks.

Janne Vilkuna är FD i etnologi, arbetade arren 1980-89 vid Mellersta Finlands museum, Jyväskylä, är sedan 1989 överassistent $i$ museologi vid Institutionen for konsthistoria, Jyväskylä universitet, cheffor universitetets museum, ledamot $i$ Finlands museiforbunds styrelse (Adr: Institutionen for konsthistoria, PI Box 35, SF-40351 Jyväskylä). 